\title{
The Role of Friction Stir Processing (FSP) Parameters on TiC Reinforced Surface Al7075-T651 Aluminum Alloy
}

\author{
Felipe García-Vázquez ${ }^{1 *}$, Benjamín Vargas-Arista², Rodrigo Muñiz , Juan Carlos Ortiz ${ }^{1}$ Héctor Hernández García ${ }^{3}$, \\ Jorge Acevedo ${ }^{3}$ \\ 1 Universidad Autónoma de Coahuila, Facultad de Ingeniería, Arteaga, Coahuila, México. \\ 2 Instituto Tecnológico de Tlalnepantla, División de Estudios de Posgrado e Investigación, Tlalnepantla, Estado de México, \\ México. \\ 3 Corporación Mexicana de Investigación en Materiales - COMIMSA, Saltillo, México.
}

Received: 01 Sept., 2016

Accepted: 09 Jan., 2017

E-mail: gv.felipe@gmail.com (FGV)

\begin{abstract}
Aluminum alloys are very promising for structural applications in aerospace, military and transportation industries due to their light weight, high strength-to-weight ratio and excellent resistance to corrosion. In comparison to unreinforced aluminum alloys, aluminum/aluminum alloy matrix composites reinforced with ceramic phases exhibit higher strength and hardness, improved tribological characteristics. A novel surface modifying technique, friction stir processing (FSP), has been developed for fabrication of surface composite with an improved performance. The effect of FSP parameters such as number of passes, direction of each pass, sealed or unsealed groove on microstructure was investigated. In this work, nano-particles of $\mathrm{TiC}$ ( $2 \%$ in weight) were added to aluminum alloy AA7075-T651 to produce a functional surface. Fixed parameters for this AA7075 alloy were used; rotation speed of $1000 \mathrm{rpm}$, travel speed of $300 \mathrm{~mm} / \mathrm{min}$ and pin penetration of $2.8 \mathrm{~mm}$. Optical microscopy (OM), scanning electron microscopy (SEM) and atomic force microscopy (AFM) were employed to study the microstructure of the fabricated surface composites. The results indicated that the selected FSP parameters influenced the area of surface composite, distribution of TiC particles and micro-hardness of the surface composites. Finally, in order to evaluate rate wear the pin on disk test was carried out.
\end{abstract}

Key-words: Friction Stir Processing (FSP); Nano-particles; Aluminum alloy 7075; Surface composite; Wear.

\section{Efeito dos Parâmetros do Proceso de Fricção Agitação para Reforçar Uma Placa de Aluminio Al7075-T651 com TiC}

Resumo: As ligas de alumínio são promissoras para aplicações estruturais nas indústrias aeroespaciais e de transporte devido ao seu elevada relação resistência-peso e excelente resistência à corrosão. Em comparação com as ligas de alumínio não reforçadas e alumínio/compósitos de matriz de alumínio reforçados com fases cerâmicas, exibem maior resistência e características tribológicas melhoradas. Foi desenvolvida uma técnica de modificação superficial, friction stir processing, para a fabricação de superfície de compósitos. Foi investigado o efeito dos parâmetros FSP como número de passes, direção de cada passe e ranhura selado ou não selada. Neste trabalho, nanopartículas de TiC ( $2 \%$ em peso) foram adicionadas à liga de alumínio AA7075-T651 para produzir uma superfície funcional. Foram utilizados parâmetros fixos para a liga AA7075: velocidade de rotação de $1000 \mathrm{rpm}$, velocidade de deslocamento de $300 \mathrm{~mm} / \mathrm{min}$ e penetração do pino de 2,8 mm. Microscopia óptica (MO), microscopia eletrônica de varredura (MEV) e microscopia de força atômica (AFM) foram utilizadas para estudar a microestrutura. Os resultados indicaram que os parâmetros FSP selecionados influenciaram na área da superfície do compósito, na distribuição de partículas de TiC e na microdureza da superfície. Finalmente, a fim de avaliar a taxa de desgaste o teste de pino sobre disco foi realizado.

Palavras-chave: Processamento por Fricção Agitação (FSP); Nanopartículas; Liga de alumínio 7075; Superfície do compósito; Desgaste.

\section{Introduction}

The strong demand for weight reduction in car and aircraft fabrication urges the optimization of the design of products employing low weight materials. The replacement of conventional materials by lighter metals such as aluminum alloys is, therefore, highly
This is an Open Access article distributed under the terms of
the Creative Commons Attribution Non-Commercial License which permits unrestricted non-commercial use, distribution, and reproduction in any medium provided the original work is properly cited. 
desirable. However, aluminum alloys are not sufficiently stiff or strong for many purposes and their reinforcement is necessary. Aluminum based metal matrix composites (Al-MMCs) exhibit high strength, larger elastic modulus, adequate wear, creep and fatigue resistance making them suitable for engineering applications [1,2]. However, Al composites also suffer from low ductility and toughness due to incorporation of brittle ceramic reinforcements, which limits their applications [3]. In this sense, it may however be noted that there are many applications in which only surface properties play an important role, as for instance, wear resistance. In these situations, only the surface layer needs to be reinforced by ceramic phases, while the bulk of the component should retain the original composition and structure with higher toughness [4]. The presence of reinforcing particles produces very attractive properties non-attainable by other materials [5]. Dispersion of nano-sized reinforcements on metallic substrate to produce surface metal matrix nano-composite (SMMNC) and the control of its distribution are difficult to achieve by conventional surface treatments [6].

Friction stir processing (FSP) is a new solid-state processing technique for microstructural modification $[7,8]$, which was developed based on the principle of friction stir welding (FSW) [9]. The basic concept of FSP is remarkably simple. A rotating tool with a pin and shoulder is inserted into a single piece of material and traversed along the desired path to cover the region of interest and these results in significant microstructural changes in the processed zone due to intense plastic deformation, mixing, and thermal exposure of material. The characteristics of FSP have led to several applications for microstructural modification in metallic materials, surface composites [1], homogenization of nanophase aluminum alloys metal matrix composites [10,11], and microstructural refinement of cast aluminum alloys [12]. Several researches reported the fabrication of SMMC via FSP, using this particle pre-placed method [13-15]. Critical control of processing parameters is necessary to obtain ideal solidified microstructure in surface layer. Obviously, if processing of surface composite is carried out at temperatures below melting point of substrate, the problems mentioned above can be avoided [16]. Different methods have been reported on literature to create a composite surface by means of FSP $[17,18]$. One of them is by mechanizing a groove in the plate surface, deposit the powder over the surface or inside on a groove and then friction stir process on top of the groove.

\section{Experimental Procedure}

In this work 7075 T651 plates of dimensions $300 \times 150 \times 10 \mathrm{~mm}$ were used as substrate, with nominal chemical composition as indicated in Table 1. Two different powders were added by Friction Stir Processing (FSP) to the substrate: pre-alloyed 7075 (as received) and mechanical alloyed 7075 with $2 \%$ nano-TiC. Pre-alloyed 7075 powder aluminum alloy (90.53 Al, $5.14 \mathrm{Zn}, 2.51 \mathrm{Mg}, 1.46 \mathrm{Cu}, 0.25 \mathrm{Cr}, 0.074 \mathrm{Fe}$ and $0.035 \mathrm{Si}$ ) with an average size of $30 \mu \mathrm{m}$ was used. TiC particles with purity of $99 \%$ and average particle size of $20 \mathrm{~nm}$ were used as reinforcement. A cyclic process of mechanical alloying, typical in ductile materials, was carried out with an attrition mill.

Table 1. Chemical composition of 7075 T651 plates (wt. \%).

\begin{tabular}{cccccccccc}
\hline Mg & Si & Fe & Cr & Cu & Zn & Mn & Ti & Al \\
2.8 & 0.05 & 0.15 & 0.01 & 1.93 & 5.92 & 0.01 & 0.02 & Balance \\
\hline
\end{tabular}

\subsection{Powders preparation}

First the mechanical alloying cyclic operation mode was performed with a $48 \mathrm{~s}$ high rotary speed of $1300 \mathrm{rpm}$ and a $12 \mathrm{~s} \mathrm{low}$ rotary speed of $1000 \mathrm{rpm}$ (1 min cycle) during $480 \mathrm{~min}$. Powder oxidation was prevented using an argon atmosphere and $0.5 \%$ of process control agent (Licowax $\mathrm{C}$ from Clariant) which, furthermore, reduces the excessive cold welding between AA7075 particles at the beginning of the mechanical alloying. Initial crystallite size for the pre-alloyed 7075 is $80 \mathrm{~nm}$ while crystallite size for the mechanical alloyed 7075 with $2 \%$ nano-TiC after $480 \mathrm{~min}$ is almost $22 \mathrm{~nm}$.

\subsection{Friction stir proccesing}

The samples were friction stir processed with a linear area of 8 centimeters on a friction stir welding machine PDS-4 Intelligent-Stir (MTS). A FSW tool with tapered pin of $5 \mathrm{~mm}$ in its widest part and $4 \mathrm{~mm}$ in its shortest part; pin length of $2.8 \mathrm{~mm}$ and shoulder diameter of $12 \mathrm{~mm}$ was used to closed the groove. Pin material is MP159 alloy 
and shoulder material is $\mathrm{H} 13$ steel. For the closed groove, a pinless tool made of $\mathrm{H} 13$ was employed. In previous work, it was found a suitable combination of parameters for processing this alloy (7075 T651) was $1000 \mathrm{rpm}$, $300 \mathrm{~mm} / \mathrm{min}, 1.5^{\circ}$ tilt angle and $8 \mathrm{kN}$ of forge force. Based on this set of parameters, changes in other parameters such as groove condition, type of powder, number and direction of passes were analyzed as indicated in Table 2 .

Table 2. FSP samples and parameter conditions.

\begin{tabular}{ccccc}
\hline Sample & Groove condition & Type of powder & Number of passes & Direction of $\mathbf{2}^{\text {nd }}$ pass \\
S1 & Closed & 7075 & 1 & ---- \\
S2 & Closed & 7075 & 2 & Same \\
S3 & Closed & $7075+\mathrm{TiC}$ & 1 & ---- \\
S4 & Closed & $7075+\mathrm{TiC}$ & 2 & Same \\
S5 & Closed & $7075+\mathrm{TiC}$ & 2 & Opposite \\
S6 & Opened & $7075+\mathrm{TiC}$ & 2 & Opposite \\
S7 & Closed & 7075 & 2 & Opposite \\
S8 & Opened & 7075 & 2 & Opposite \\
S9 & Opened & $7075+\mathrm{TiC}$ & 1 & ---- \\
S10 & Opened & $7075+\mathrm{TiC}$ & 2 & Same \\
\hline
\end{tabular}

\subsection{Microstructural characterization}

Micrographs were performed by OM, JEOL scanning electron microscope (SEM) equipped with EDXS semi quantitative analysis using an accelerating voltage of $15 \mathrm{kV}$, spot size of 40 and a working distance of $11 \mathrm{~mm}$ and atomic force microscopy (AFM). Specimens were mounted, polished up to $0.05 \mu \mathrm{m}$ with colloidal alumina and finally etched with $\mathrm{HF} 0.5 \%$.

\subsection{Wear and hardness tests}

Pin on disk tests with circular track were performed on the stirred surface with a high temperature tribometer Microtest MT2/60/SCM. Wear tests were performed on $5 \mathrm{~cm} \times 5 \mathrm{~cm}$ plates with a $1 \mathrm{~cm}$ of diameter of the track for $32 \mathrm{~min}$ against a $4 \mathrm{~mm}$ rotating steel ball (AISI 52100) at the constant load of $10 \mathrm{~N}$ and a sliding speed of $0.026 \mathrm{~m} / \mathrm{s}$. Hardness tests on the transverse section were carried out in a microhardness tester SHIMADZU using $1 \mathrm{~kg}$ load, were performed 29 indentations over the samples.

\section{Results and Discussion}

\subsection{Microstructural characterization}

Figure 1 shows optical macrographs of all the cross section of the samples (S1-S10) processed with different conditions. As can be observed, there are not defects such as voids or cracks observed on the surface of the FSP samples. The top surface shows very smooth quality and there are almost no prominences or depressions, due to the tool stirring. Macrostructure for all samples is very similar. No gross defects such as voids or tunnel defect are detected and a homogeneous processed zone is visible in all samples.

Advancing side (A. S.) and retreating side (R. S.) for samples S5, S6, S7 and S8 correspond to the second pass. S1 and S3 correspond with samples processed in the same conditions with pre-alloyed AA7075 and mechanical alloyed AA7075 with TiC addition, respectively. Mechanical alloyed powder with ceramic TiC particles are less plastic and cause a wider nugget than when original 7075 powder is used. In addition, differences can be found between samples processed when mechanical alloyed reinforced AA7075 powder is used with 1 (S3) or 2 passes (S4). Again, more material around the pin is plasticized when 2 passes are carried out. Finally, in samples S3, S4, S5, S6, S9 and S10 processed with TiC powder reinforcement, the distribution of TiC particles is not uniform. The sealing of the groove results in more TiC incorporated ( 33 compared with $\mathrm{S} 9$ and $\mathrm{S} 5$ with $\mathrm{S6}$ ). 


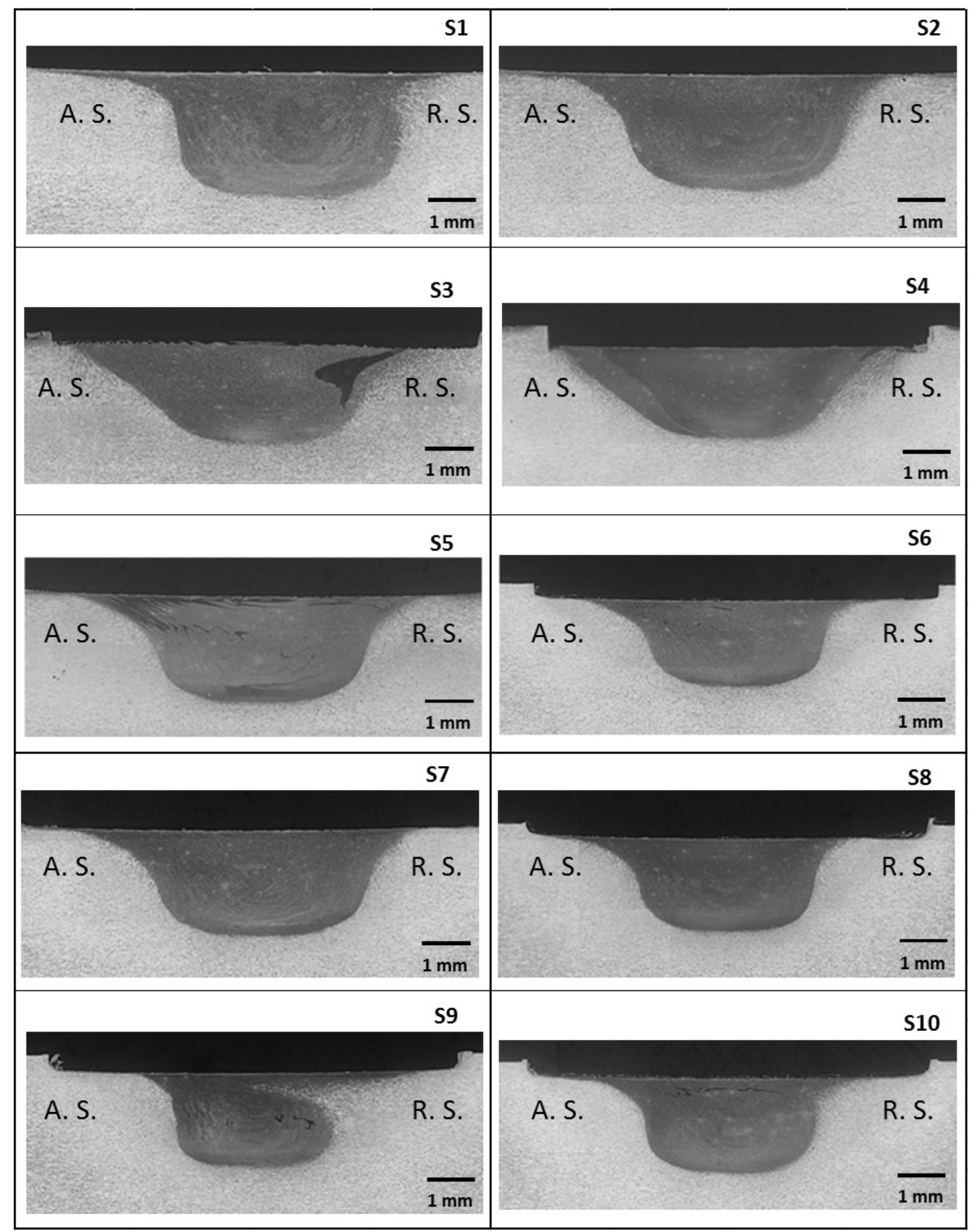

Figure 1. Optical macrographs of the cross section of all samples with different conditions.

Figure 2 shows a comparison of TiC distribution zones between samples S3 and S5. S3 was conducted with 1 pass and S5 with 2 passes. As can be appreciated in Figure 2a, b sample S3 has the TiC distribution agglomerated at the retreating side. Therefore, is necessary a second pass in order to achieve a suitable distribution. 55 presented more homogeneous distribution of TiC particles at the surface (Figure 2c, d). This sample was processed with sealed groove and two passes on opposite direction. Therefore, darker zones in Figure 2a, c correspond to TiC reinforced AA7075 zones. The results with this double pass are consistent with previous research about multi-pass FSP [19]. It was observed that FSP refines the microstructure and provides a convenient method to improve the surface properties of aluminum alloy by forming surface composites. 


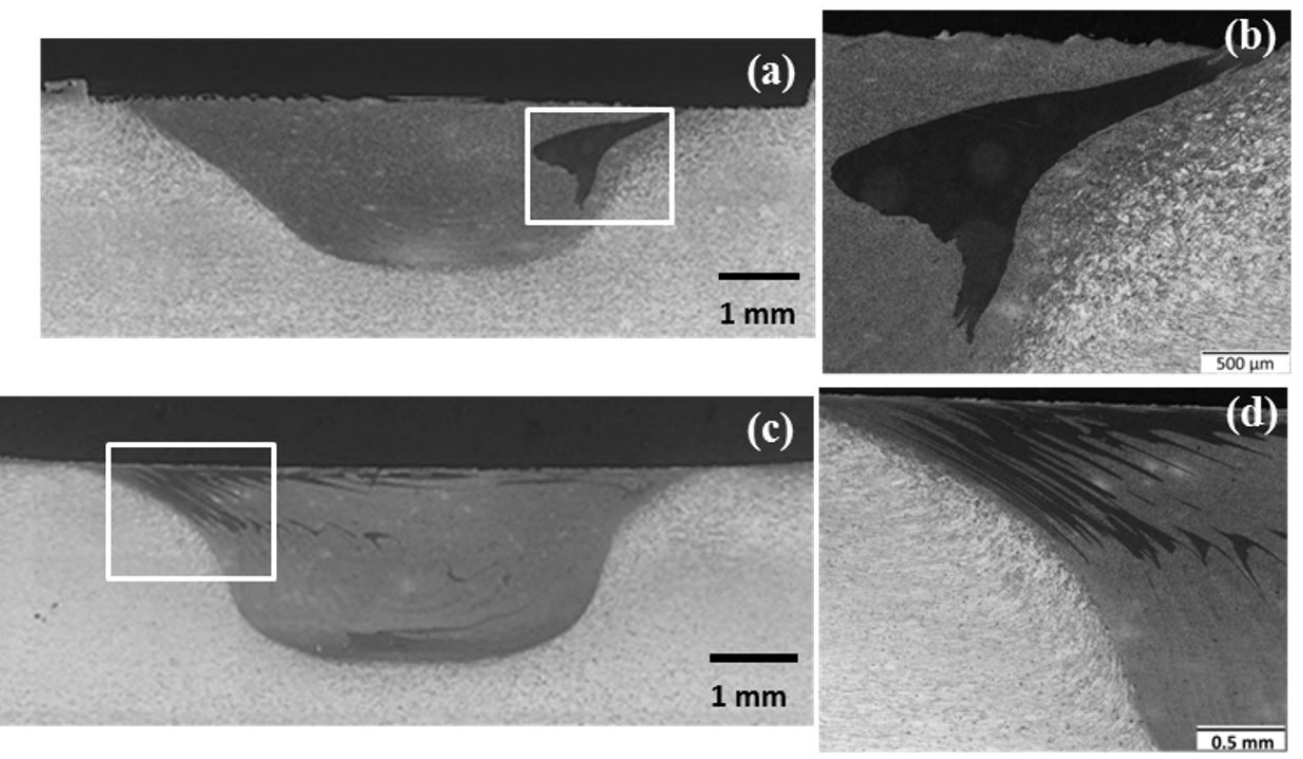

Figure 2. (a) and (c) cross section of the sample S3 and S5, respectively; (b) and (d) amplified zones of the TiC particle distribution.

Figure 3a shows a SEM micrograph corresponding with this dark zone and the EDS analysis is shown in Figure $3 \mathrm{~b}$. Very small quantity of $\mathrm{Ti}$ is observed due to the low percentage of reinforcement in the AA7075 mechanical alloyed powders. It is not possible to differentiate the TiC particles because of their nanometric size. On the other hand, can be appreciated high level of Al, with $\mathrm{Zn}$ and $\mathrm{Mg}$.
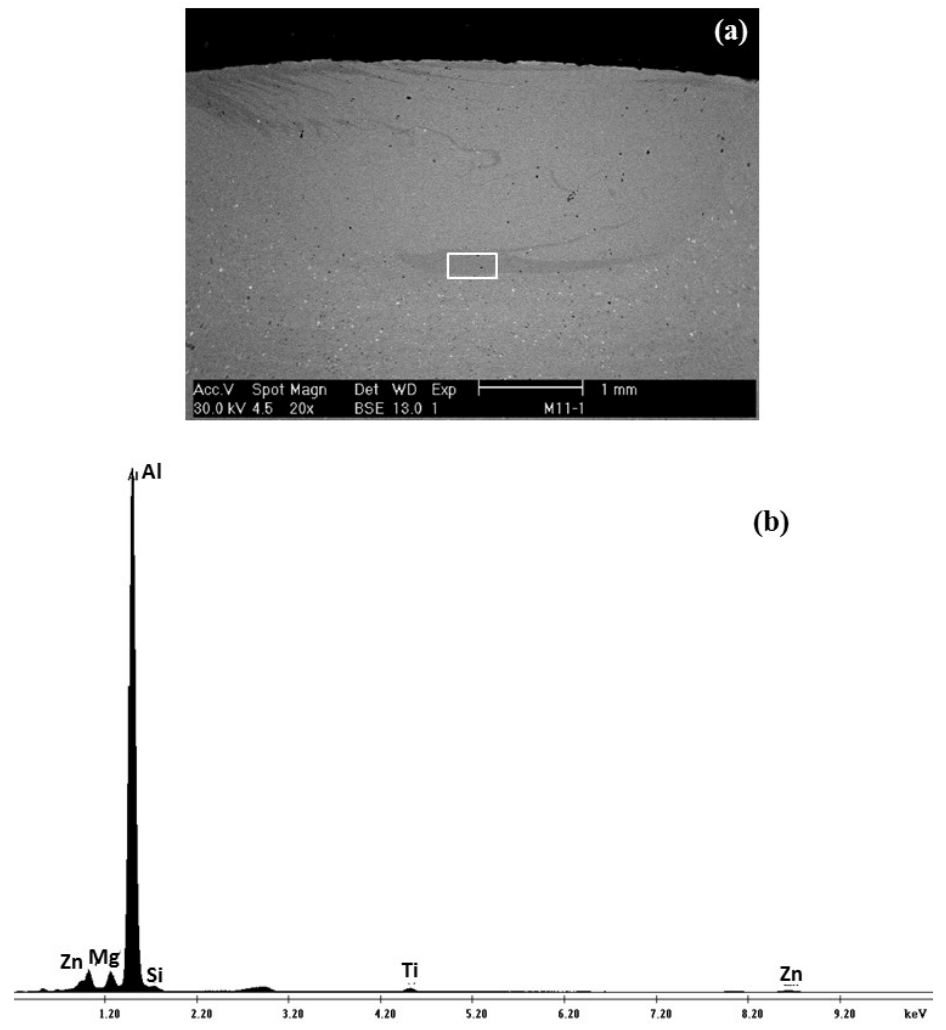

Figure 3. (a) SEM image of the particle distribution on sample S5; (b) EDS spectrum of the zone indicated in the rectangle. 
Also an EDS element mapping was conducted as can be observed at Figure 4. In Figure 4a is presented the analysis corresponding to darker zone in sample $\mathrm{S} 3$ and Figure $4 \mathrm{~b}$ corresponds to sample $\mathrm{S} 5$. As can be appreciated, there are small quantities of Ti which confirm the presence of TiC in that zone.
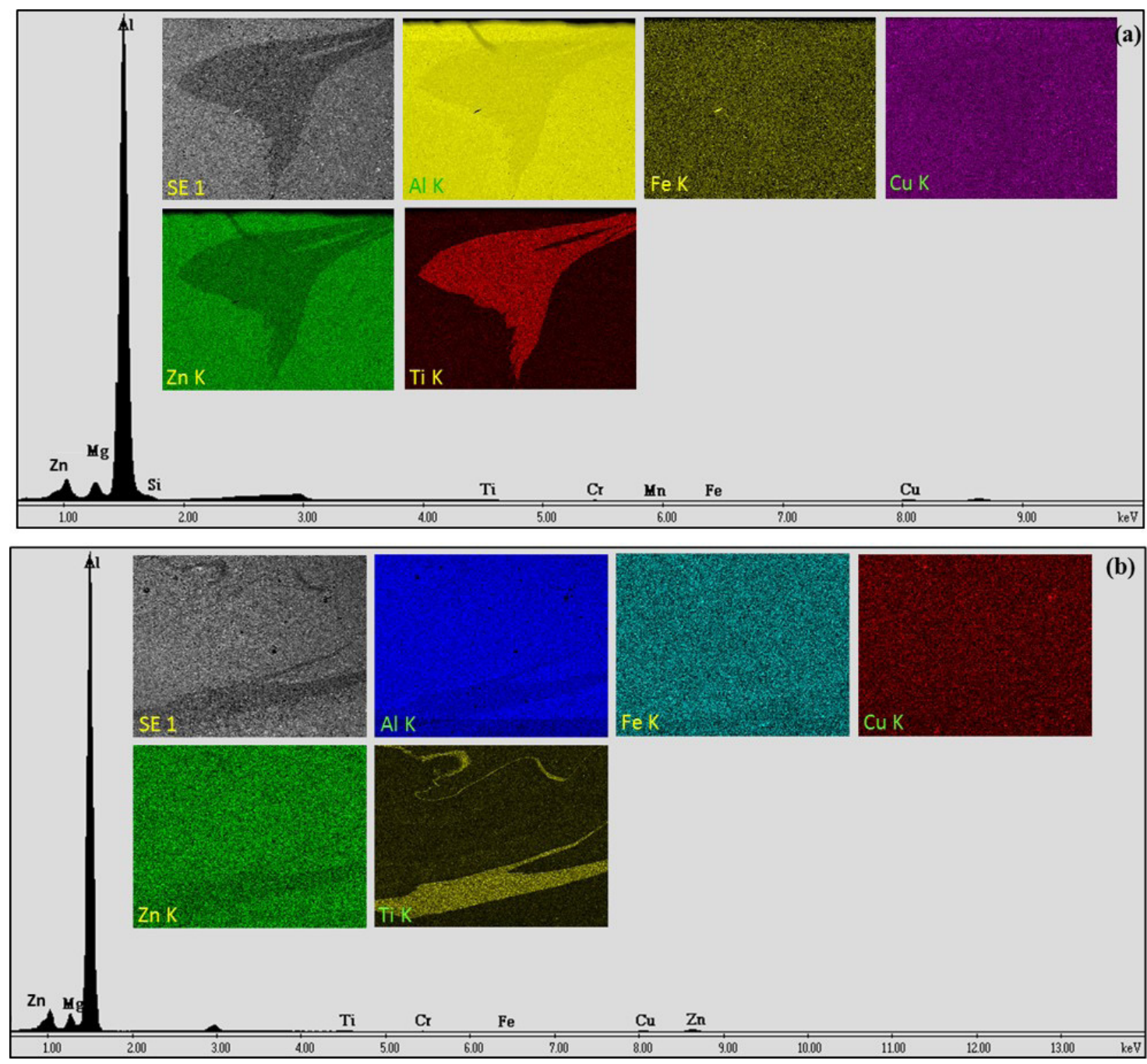

Figure 4. EDS element mapping on the darker zones in (a) sample S3 and (b) sample S5.

On the other hand, in order to analyze the topography at the interface of TiC regions, AFM was performed. In this case, the contact mode was used to obtain an image corresponding to the topography of the surface through direct contact with the tip, the contact forces causing the cantilever to bend to accommodate changes in topography. In Figure 5 a can be appreciated an image with the regions of AFM analysis. Figures $5 b, c$ correspond to the analysis at region 1 and 2, respectively. In both topography analyses are showed that regions at the interface between TiC reinforcement and base metal alloy present a decline of the surface. The plastic flow during FSP generates an interaction between TiC and $7075 \mathrm{Al}$ powders causing that effect at the topography. AFM also demonstrates the presence of TiC distributed at the processed stir zone using FSP.

\subsection{Micro-hardness}

The Vickers hardness of the base metal alloy was about $195 \mathrm{HVN}$. As a result of FSP, the average hardness measured on the stirred zone was $150 \mathrm{HVN}$ according to Figure 6. Hardness decreases due to the FSP thermal treatment affects the $T 651$ initial treatment resulting in lower hardness in the nugget, thermo mechanically affected 
zone (TMAZ) and heat affected zone HAZ. The micro-hardness pattern of the samples exhibits the "W" shape for all samples. The two troughs of the $\mathrm{W}$ are located in the TMAZ and the crest occurs in the nugget zone. A comparison between samples processed with the reinforced powder and with 2 passes, show that the hardness is higher in the nugget for the samples with the sealed groove (S4 and S5) compared with the unsealed ones (S6 and S10). In sealed
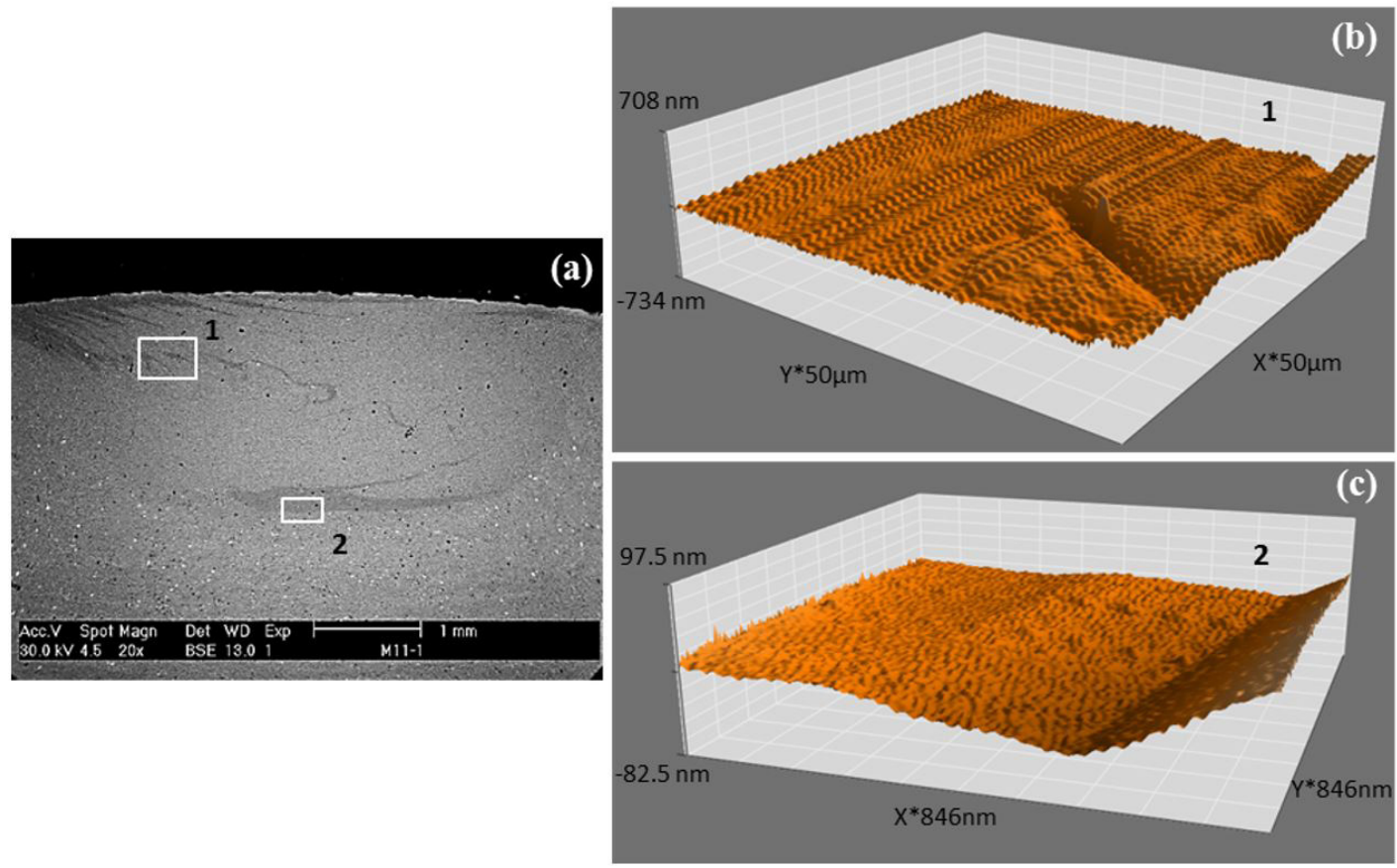

Figure 5. (a) SEM micrograph illustrating the regions of obtaining images with AFM; (b) region 1, field of view $50 \mu \mathrm{m}$ and (c) region 2, field of view $846 \mathrm{~nm}$.

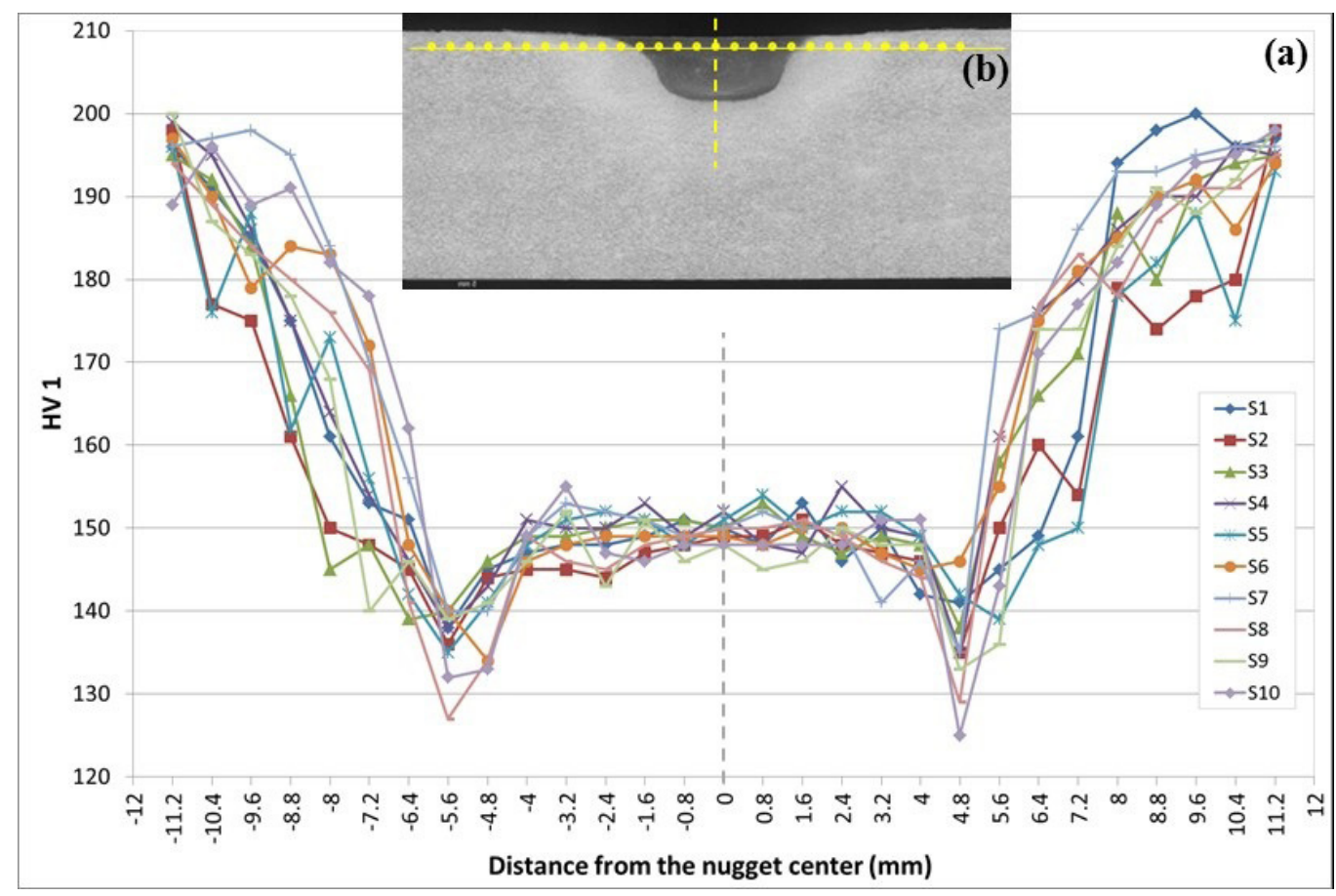

Figure 6. (a) Distribution of the microhardness values along the cross section of the samples and (b) image illustrating the measurement zones. 
samples, the powder remains into the groove while the pin tool stirs the base material with the powder. When the effect of the direction of the second pass is compared, for unsealed samples, more homogeneous hardness values are observed throughout the nugget for S6 (opposite direction for the second pass).

\subsection{Wear}

Figure 7 illustrates the specific wear rate coefficient, $K$, for the samples and base metal (BM). All the samples presented a decreased wear resistance that can be attributed to the softening of the aluminum. Perhaps, the small quantity of $2 \%$ nano-TiC is not enough to increase the wear resistance on the surface, counteracting the softening due to the elimination of the T651 thermal treatment. On the other hand, the best wear rate of the samples corresponded to S5, which presented a homogeneous distribution of TiC particles on the surface of the stir zone. Despite sample S3 was processed with TiC particles and one pass, it presented a higher wear rate value. This higher wear rate is related with not homogeneous distribution of the TiC reinforced powder.

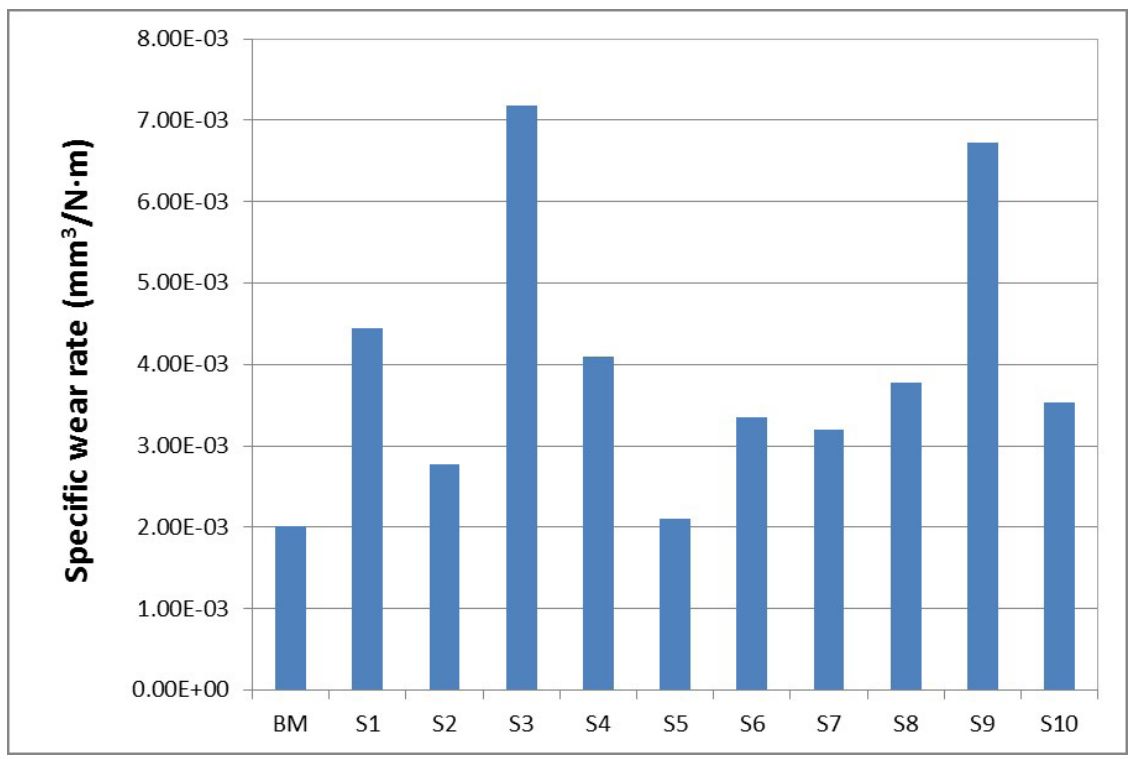

Figure 7. Specific wear rate coefficient $(K)$.

\section{Conclusions}

There are not defects and a homogeneous stir zone is formed in the processed samples with unreinforced and reinforced AA7075 powder. Nevertheless, the type of powder incorporated (with or without TiC) and the number of FSP passes cause differences in the nugget. Sample S5 processed with sealed groove and two passes on opposite direction exhibited more homogeneous distribution of TiC particles at the processed zone. This sample also presented the lower wear rate due to a homogeneous distribution of TiC particles on the surface of its stir zone. Hardness decreases in the stirred zone in all samples as a consequence of the plastic deformation of the material. FSP is a suitable technique to incorporate particles reinforcement on the surface of metal alloys. Additional tests with more quantity of TiC reinforcement have to be made to counteracting the hardening decrease in the processed zone.

\section{References}

[1] Mishra RS, Ma ZY, Charit I. Friction stir processing: a novel technique for fabrication of surface composite. Materials Science and Engineering A. 2003;341(1-2):307-310. http:// dx.doi.org/10.1016/S0921-5093(02)00199-5.

[2] Cavaliere P. Composites part A: applied science and manufacturing. Heidelberg: Elsevier; 2005. (vol. 36).
[3] Mishra RS, Ma ZY. Friction stir welding and processing. Materials Science and Engineering R Reports. 2005;50(1-2):1-78. http:// dx.doi.org/10.1016/j.mser.2005.07.001.

[4] Mahmoud ERI, Takahashi M, Shibayanagi T, Ikeuchi K. Wear characteristics of surface-hybrid-MMCs layer fabricated on aluminium plate by Friction Stir Processing. Wear. 2010;268(910):1111-1112. http://dx.doi.org/10.1016/j.wear.2010.01.005. 
[5] Mcguire PF. Aluminum composites come in for a landing. Mach Des. 1992;64:71-74.

[6] Lee CJ, Huang JC, Hsieh PJ. Mg based nano-composites fabricated by friction stir processing. Scripta Materialia. 2006;54(7):14151420. http://dx.doi.org/10.1016/j.scriptamat.2005.11.056.

[7] Mishra RS, Mahoney MW, Mcfadden SX, Mara NA, Mukherjee AK. High strain rate superplasticity in a friction stir processed 7075 Al alloy. Scripta Materialia. 2000;42(2):163-168. http:// dx.doi.org/10.1016/S1359-6462(99)00329-2.

[8] Mishra RS, Mahoney MW. Friction stir processing: a new grain refinement technique to achieve high strain rate superplasticity in commercial alloys. Mater Sci Forum. 2001;357-3:507-512.

[9] Thomas WM, Nicholas ED, Needham JC, Murch MG, Templesmith P, Dawes CJ. GB Patent Application No. 9125978.8. 1991.

[10] Berbon PB, Bingel WH, Mishra RS, Bampton CC, Mahoney MW. Friction stir processing: a tool to homogenize nanocomposite aluminum alloys. Scripta Materialia. 2001;44(1):61-66. http:// dx.doi.org/10.1016/S1359-6462(00)00578-9.

[11] Spowart JE, Ma ZY, Mishra RS, Jata KV, Mahoney MW, Semiatin $\mathrm{SL}$, et al. Friction stir welding and processing II. Warrendale: TMS; 2003. p. 243-252.

[12] Ma ZY, Sharma SR, Mishra RS, Mahoney MW. Microstructural modification of cast aluminum alloys via friction stir processing. Materials Science Forum. 2003;2891:426-432.

[13] Nakata K, Kim YG, Fujii H, Tsumura T, Komazaki T. Improvement of mechanical properties of aluminum die casting alloy by multi-pass friction stir processing. Materials Science and Engineering A. 2006;437(2):274-280. http://dx.doi.org/10.1016/j. msea.2006.07.150.

[14] Morisada Y, Fujii H, Nagaoka T, Fukusumi M. Effect of friction stir processing with $\mathrm{SiC}$ particles on microstructure and hardness of AZ31. Materials Science and Engineering A. 2006;433(1-2):5054. http://dx.doi.org/10.1016/j.msea.2006.06.089.

[15] Johannes LB, Yowell LL, Sosa E, Arepalli S, Mishra RS. Survivability of single-walled carbon nanotubes during friction stir processing. Nanotechnology. 2006;17(12):3081-3084. http://dx.doi. org/10.1088/0957-4484/17/12/044.

[16] Gui, Kang SB. 6061Al/AI-SiCp bi-layer composites produced by plasma-spraying process. Materials Letters. 2000;46(5):296302. http://dx.doi.org/10.1016/S0167-577X(00)00191-9.

[17] Shafiei-Zarghani A, Kashani-Bozorg SF, Zarei-Hanzaki A. Microstructures and mechanical properties of A1/A1203 surface nano-composite layer produced by friction stir processing. Materials Science and Engineering A. 2009;500(1-2):84-91. http://dx.doi.org/10.1016/j.msea.2008.09.064.

[18] Sert A, Celik ON. Wear behavior of SiC reinforced surface composite A17075-T651 aluminum alloy produced using friction stir processing. Indian Journal of Engineering and Materials Sciences. 2014;21:35-43.

[19] Ma ZY, Sharma SR, Mishra RS. Effect of multiple-pass friction stir processing on microstructure and tensile properties of a cast aluminum-silicon alloy. Scripta Materialia. 2006;54(9):16231626. http://dx.doi.org/10.1016/j.scriptamat.2006.01.010. 